\title{
Differences in the generation of industrial waste from economic activities in Ukraine and the EU and the prospects for the integrated use of mineral raw materials
}

\author{
Victoria Gubina ${ }^{1,}$, Victor Zaborovsky ${ }^{1}$, Natalia Mitsiuk ${ }^{1}$, and Aboubaker Farag Srat ${ }^{2}$ \\ ${ }^{1}$ State Institution "The Institute of Environmental Geochemistry of National Academy of Sciences of Ukraine", \\ 34a Palladin Ave., Kyiv, 03142, Ukraine \\ ${ }^{2}$ Alfatech University, CC 82668, Tripoli, Libya
}

\begin{abstract}
The paper presents the comparative analysis of the amount of waste generated in Ukraine and European countries (except for radioactive waste) based on the official EU and Ukrainian statistical data. The data on waste generation are compiled according to the following classification: by economic activity and household, waste category, grades of hazard, and regions. In Ukraine, 352.3 million tons of waste was generated in 2018. By 2018, almost 13 billion tons of waste had been accumulated at the managed dumpsites, including about 12 million tons of hazardous and over 200 million tons of household waste. In the European Union, 2.6 billion tons of waste was generated in 2018. Over 70\% of it was generated by 10 countries: Germany, France, England, Poland, Romania, Italy, Sweden, the Netherlands, Spain and Finland. By economic activity, the largest amounts of waste in Ukraine are generated by the mineral extraction and processing industry, the smallest - from water treatment and construction. In the EU countries, these values are somewhat different. For example, in Germany and France, the largest amounts of waste are generated from construction and manufacturing, the smallest - from agriculture, forestry and fishery. By waste category, the waste generated both in the EU countries and in Ukraine is mineral and solid waste. In Ukraine, the largest amounts of waste are produced and accumulated in the Dnipropetrovsk, Donetsk and Zaporizhzhia regions which accommodate large enterprises for extraction and mineral processing of iron and manganese ores, titanium-zirconium placers, coal, dolomite, and metallurgical limestone, as well as metallurgical and ferroalloy plants.
\end{abstract}

\section{Introduction}

Rapid global economic growth at the end of the last millennium led to excessive use of non-renewable natural resources and increase of human impact on the environment. The amount of generated waste became one of the challenges facing humanity in the nearest future.

In accordance with the national waste management programmes, the European Union and Ukraine make inventories of the waste generated both by economic sectors and households. The waste inventories reflect the socio-economic differences and different approaches to treatment and identification of waste types. The list of waste used in Ukraine does not fully correspond to that in EU. In 2014-2017, Ukraine took initial important steps to change the situation through commitment of compliance with the EU Directives as a part of the Association Agreement with the EU and adopting the National Waste Management Strategy until 2030.

Waste statistics play an important role in understanding and monitoring respective changes in the production/consumption processes towards more sustainable solutions.
The data used in the article were taken from the Eurostat and Ukrstat databases for 2018.

The amount of waste generation in different countries varies depending on the economic activity and society's production and consumption patterns. The largest amount of waste is generated in countries with developed mining and metallurgical industries. At the same time some countries with high level of household consumption demonstrate significant generation of household and construction/deconstruction waste. Although the three biggest economies - Germany, the United Kingdom and France - have the highest generation of waste in absolute figures, no direct link between economic production and waste generation is observed for all EU countries. For example, in smaller economies like Bulgarian and Romanian, the waste generation in mining and metallurgical industries is amongst the highest.

Limited natural resources, environmental impact of rapidly growing amounts of waste require urgent measures aimed at waste reduction.

Waste management is a key environmental concern both in Europe and Ukraine. The situation in Ukraine has already proven to be critical in many cities and regions due to a lack of proper waste management infrastructure

\footnotetext{
* Corresponding author: gvg131619@gmail.com
} 
and adequate government policy, business approach and public response.

\section{Results and discussion}

According to the State Statistics Service of Ukraine (Ukrstat), over 300 million tons of waste have been generated annually from 2014 to 2018 , including 0.6 - 0.7 million tons of hazardous waste and over 10-11 million tons of household waste. By 2018, almost 13 billion tons of waste have been accumulated at the managed dumpsites in Ukraine, including about 12 million tons of hazardous and over 200 million tons of household waste (the data for the temporarily occupied Crimea and some territories of Donetsk and Luhansk regions are not included) (Table 1) [1].

Table 1. Waste generation and accumulation at the managed dump-sites in Ukraine, mln. tons.

\begin{tabular}{|c|c|c|c|c|c|c|}
\hline Year & $\begin{array}{c}\text { Total waste } \\
\text { generation }\end{array}$ & $\begin{array}{c}\text { Hazardous } \\
\text { waste }\end{array}$ & $\begin{array}{c}\text { Household } \\
\text { waste }\end{array}$ & $\begin{array}{c}\text { Total waste accumulation at } \\
\text { managed dump-sites }\end{array}$ & $\begin{array}{c}\text { Hazardous } \\
\text { waste }\end{array}$ & $\begin{array}{c}\text { Household } \\
\text { waste }\end{array}$ \\
\hline 2014 & 354.803 & 0.7 & 10.748 & 12115.241 & 11.951 & 166.112 \\
\hline 2015 & 312.267 & 0.6 & 11.492 & 12281.353 & 11.996 & 170.306 \\
\hline 2016 & 295.870 & 0.6 & 11.563 & 12451.659 & 12.102 & 174.514 \\
\hline 2017 & 366.054 & 0.605 & 11.271 & 12442.169 & 12.198 & 201.145 \\
\hline 2018 & 352.334 & 0.627 & 10.000 & 12972.428 & 2.217 & 227.435 \\
\hline
\end{tabular}

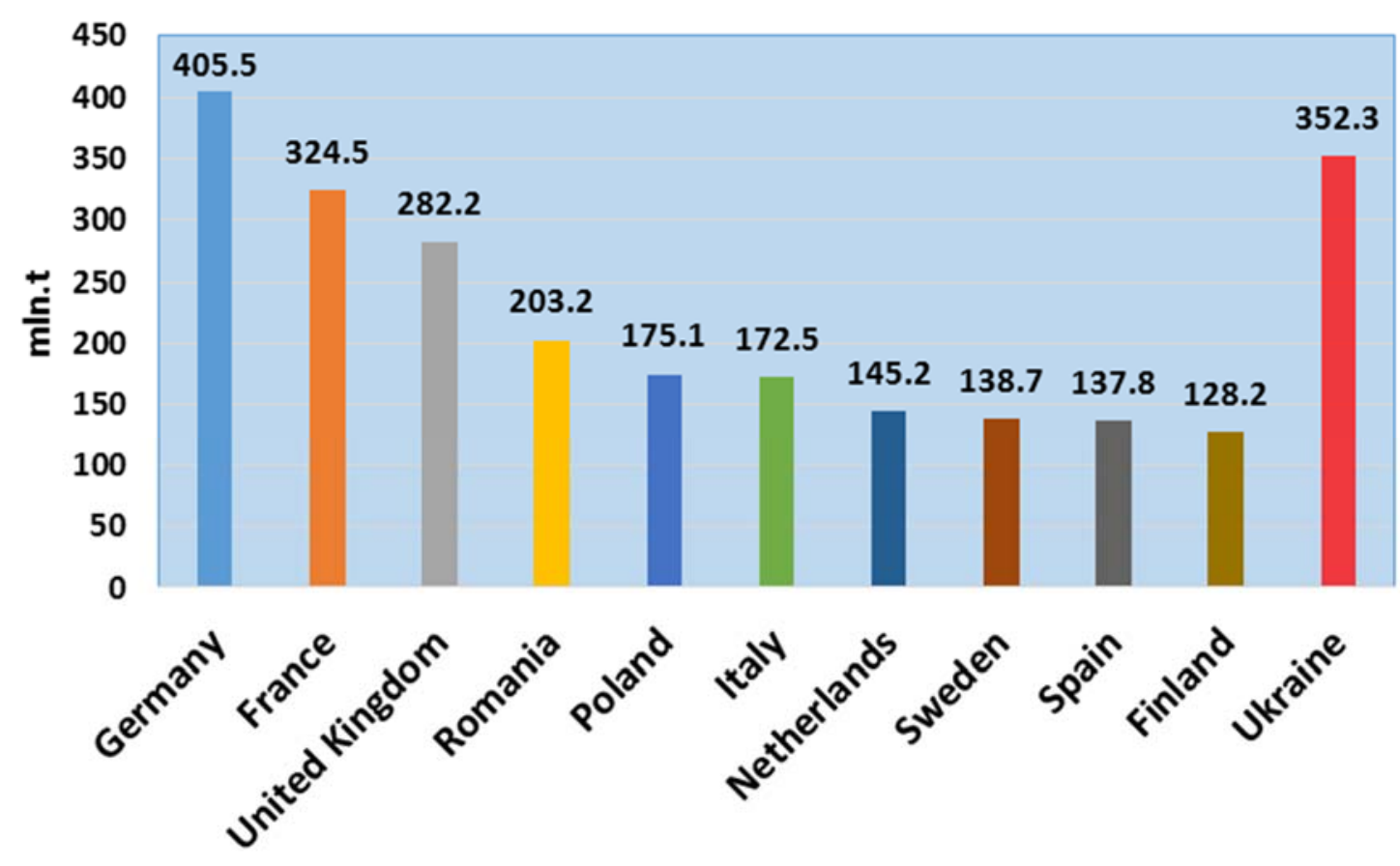

Fig. 1. Waste generated by some EU countries and Ukraine.

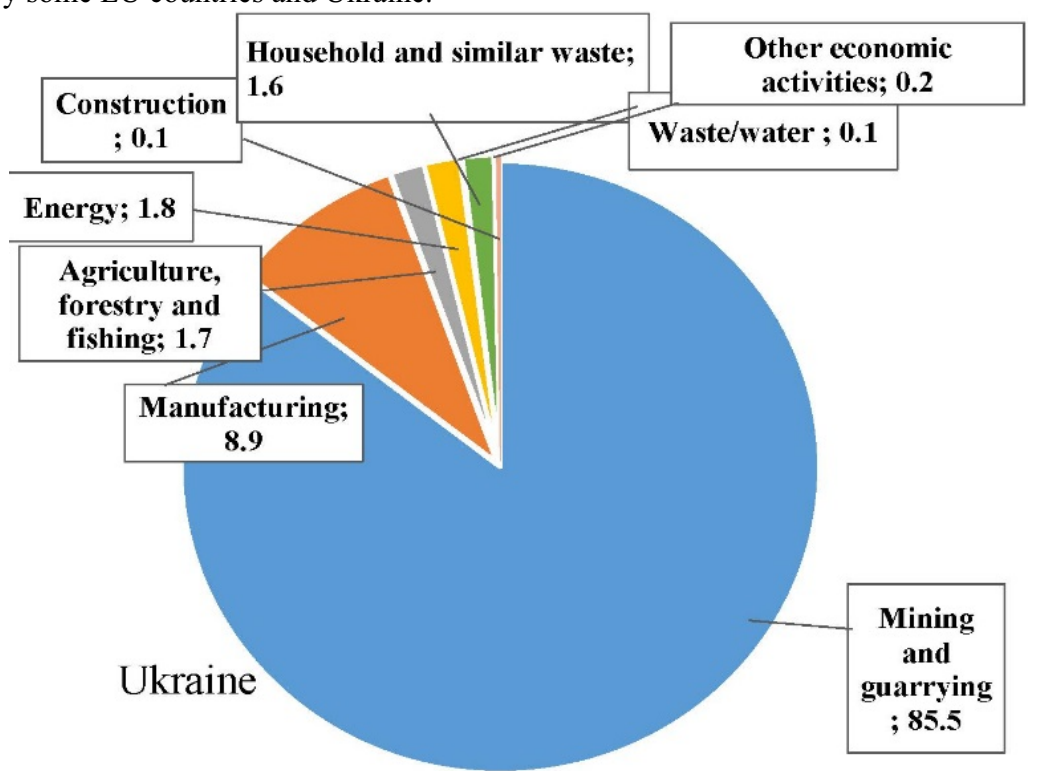

Fig. 2. Waste generation by activity in Ukraine, mln. tons. 
According to Eurostat data, 2.6 billion tons of waste was generated in the EU (EC-28) in 2018 (Fig. 1). More than $70 \%$ of it was generated by 10 countries: Germany, France, United Kingdom, Romania, Poland, Italy, the Netherlands, Sweden, Spain, and Finland [2].

As can be seen in the chart, the amount of waste generated by some European countries in 2018 in million tons was as follows: Germany - over 400, France - over 300, UK - about 280, Romania - about 200, Poland and Italy - more than 170, Netherlands, Spain and Sweden about 140, Finland - more than 120. In Ukraine, the amount of waste generated was over 350 , which is less than in Germany and more than in France and the United Kingdom.

According to Eurostat data, in 2018 the following amounts of waste ( $\mathrm{mln}$. tons) were generated by each of the following European countries: Turkey - 90, Greece, Belgium, Austria and Serbia - from 40 to 70, Czechia, Estonia and Denmark - over 20, Hungary, Ireland, Portugal - from 14 to 18, Luxembourg, Slovakia, Norway - from 12 to 14 . From 1 to 6 million tons were generated by other EU countries.

The State Statistics Service of Ukraine keeps records of waste generation and accumulation at the managed dump-sites in accordance with the National Waste Classifier. Waste is classified according to different parameters (by economic activity, waste categories, hazard classes, required disposal operations, and households). The same inventory strategy is used in the European Union.

Based on the State Statistics Service data [3], the chart in Fig. 2 presents waste generation by economic activity in Ukraine.

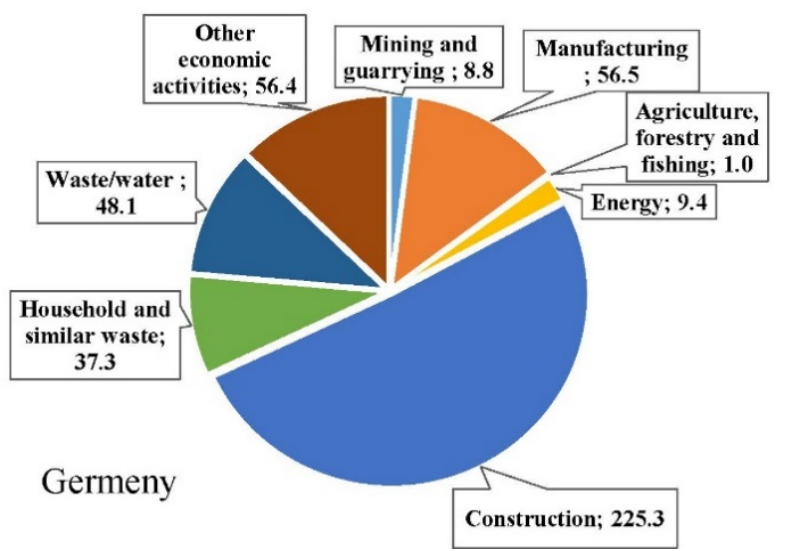

Fig. 3. Waste generation by economic activity in Germany, mln. tons.

The largest volumes of waste in Ukraine (million tons) are generated by quarrying and mining $-301.4(74.3 \%)$, and manufacturing - $31.5(17.5 \%)$, the later includes metallurgical and chemical enterprises, food industry etc. Household waste amounts to 5.5 million tons $(1.1 \%)$. For comparison, in Germany and France, the largest volumes of waste are generated by construction industry -225.3 million tons $(55.6 \%)$ and 240.2 million tons $(70.2 \%)$, and the manufacturing industry - 56.5 million tons $(13.9 \%)$ and 22.4 million tons $(6.6 \%)$ respectively. The household garbage volume is 37.3 million tons $(9.2 \%)$ in Germany and 29.7 million tons (8.7\%) in France (Figs. 3, 4) [2].
According to the State Statistics Service of Ukraine [1], the main sources of waste generation and accumulation in Ukraine are the following economic sectors (Table 2). Thus, the largest amount of waste in Ukraine is generated by quarrying and mining operations - over 300 million tons. It makes on average $74.3 \%$ of the total waste. At that, $80 \%$ is the waste from metal ore extraction (iron, manganese, titanium-zirconium). According to the National Waste Classifier, metal ore mining and quarrying waste in Ukraine include slurry and tailings, waste from pelletes and flux production (dust, powder, etc.), red mug from alumina production, and nonferrous metal ore processing waste.

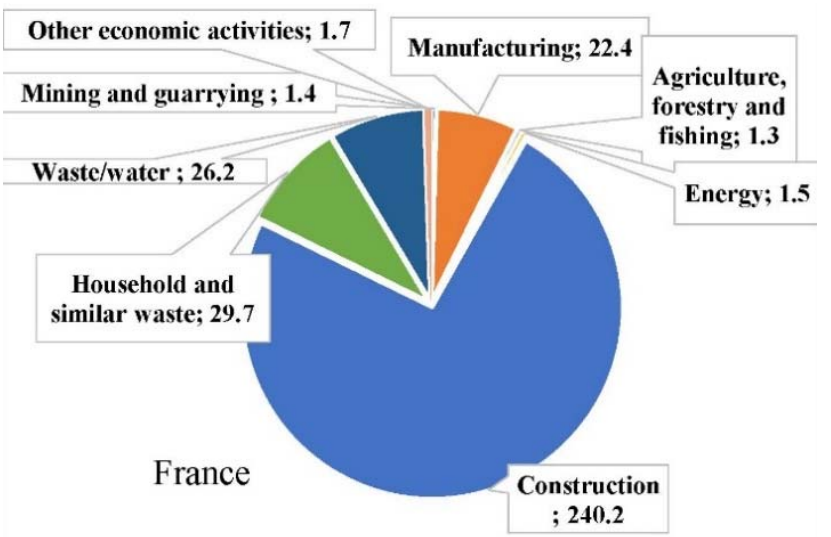

Fig. 4. Waste generation by economic activity in Germany, mln. tons.

Table 2. Dynamics of waste generation by economic activity in Ukraine, mln. tons.

\begin{tabular}{|l|l|l|l|l|l|}
\hline Economy sectors & $\mathbf{2 0 1 4}$ & $\mathbf{2 0 1 5}$ & $\mathbf{2 0 1 6}$ & $\mathbf{2 0 1 7}$ & $\mathbf{2 0 1 8}$ \\
\hline Total & 355.00 & 312.27 & 295.87 & 366.05 & 352.33 \\
\hline $\begin{array}{l}\text { Type of economic } \\
\text { activity }\end{array}$ & 348.69 & 306.21 & 289.52 & 360.20 & 346.79 \\
\hline $\begin{array}{l}\text { Agriculture, hunting, } \\
\text { and provision of } \\
\text { related services }\end{array}$ & 8.4 & 8.7 & 8.7 & 6.2 & 6.0 \\
\hline Mining (Total) & 297.2 & 252.1 & 237.3 & 313.6 & 301.3 \\
\hline Mining of metal ores & 281.5 & 238.1 & 222.5 & 293.7 & 282.5 \\
\hline $\begin{array}{l}\text { Mining of hard coal, } \\
\text { lignin and peat }\end{array}$ & 13.0 & 12.1 & 10.5 & 12.9 & 10.8 \\
\hline Mining of other ores & 2.7 & 1.9 & 4.3 & 7.0 & 8.0 \\
\hline $\begin{array}{l}\text { Manufacturing } \\
\text { industry (Total) }\end{array}$ & 29.50 & 25.60 & 28.20 & 29.60 & 28.80 \\
\hline $\begin{array}{l}\text { Iron and steel } \\
\text { production }\end{array}$ & 23.4 & 20.7 & 22.3 & 22.0 & 21.8 \\
\hline Chemical industry & 1.1 & 0.7 & 0.8 & 1.2 & 1.2 \\
\hline Food industry & 5.8 & 5.1 & 5.7 & 6.8 & 6.2 \\
\hline $\begin{array}{l}\text { Other branches of } \\
\text { mining industry }\end{array}$ & 4.5 & 4.5 & 5.3 & 2.2 & 2.3 \\
\hline $\begin{array}{l}\text { Production and } \\
\text { distribution of energy, } \\
\text { gas and steam, and air } \\
\text { conditioning }\end{array}$ & 6.0 & 6.6 & 7.5 & 6.2 & 6.3 \\
\hline $\begin{array}{l}\text { Other types of } \\
\text { economic activities }\end{array}$ & 5.0 & 2.2 & 1.8 & 2.0 & 1.6 \\
\hline Households & 6.3 & 6.0 & 6.3 & 5.9 & 5.5 \\
\hline
\end{tabular}

The group of waste from hard coal, lignin and peat mining includes substandard coal, slurry and tailings from 
concentrating mills. Other group of waste generated by Ukrainian enterprises comprises waste from mining of granite, limestone, chalk, dolomite, refractory clay, building stone and others.

On average, the manufacturing industry generates $17.5 \%$ of waste, over $69.2 \%$ of which come from the metallurgical industry (blast-furnace, steelmaking and ferroalloy slags and slurries, etc.).

The structure of metal-containing waste generated by the mining and metallurgical industries and accumulated at the managed dump-sites is shown in Fig. 5 and 6 [4, 5].

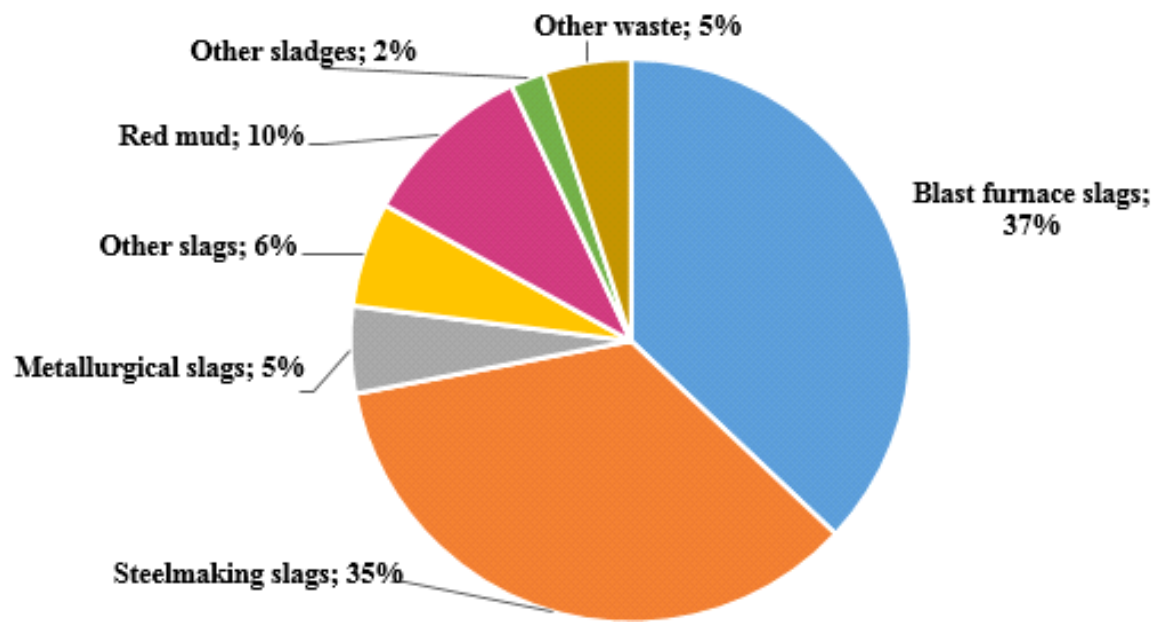

Fig. 5. Structure of waste generated from major metals production, $\%$.

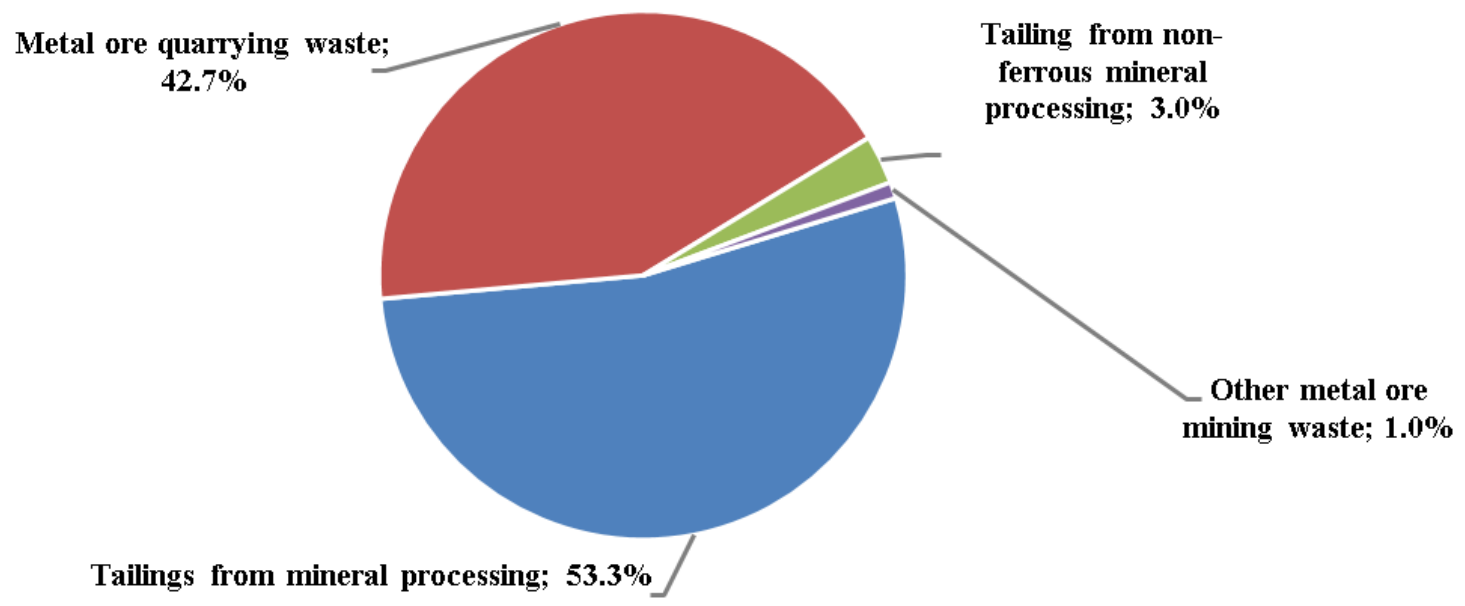

Fig. 6. Waste generated by metal ore quarrying and mining, $\%$.

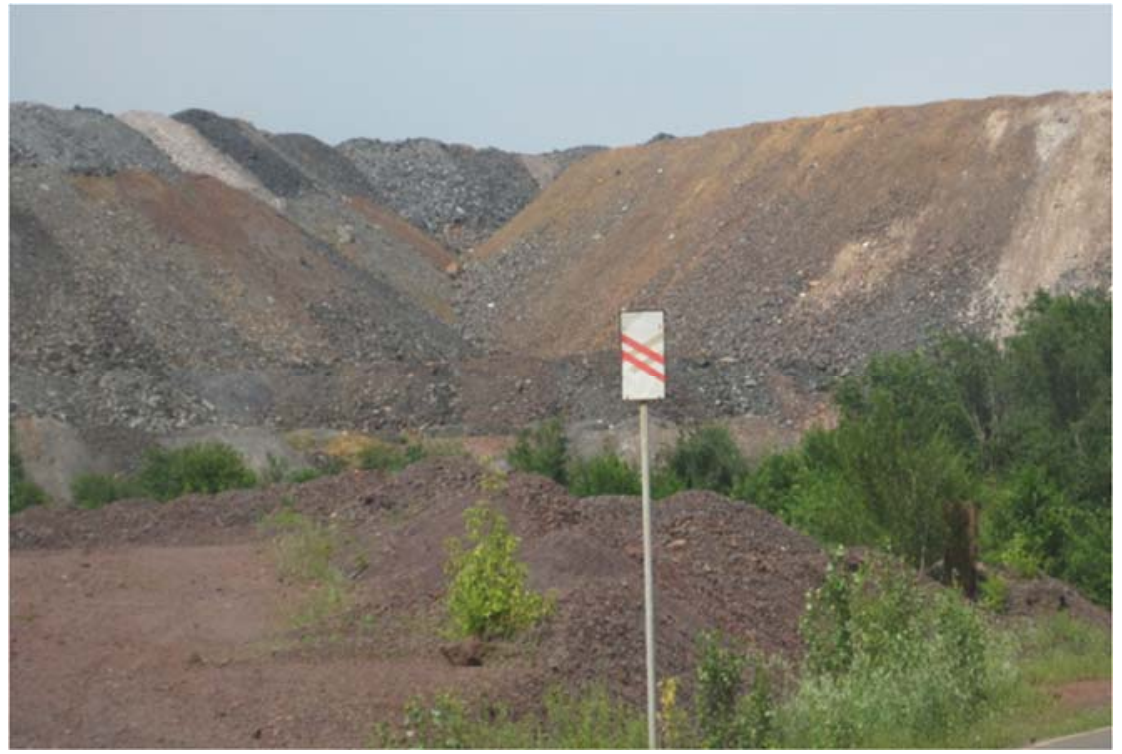

Fig. 7. Waste from iron ore quarrying. 


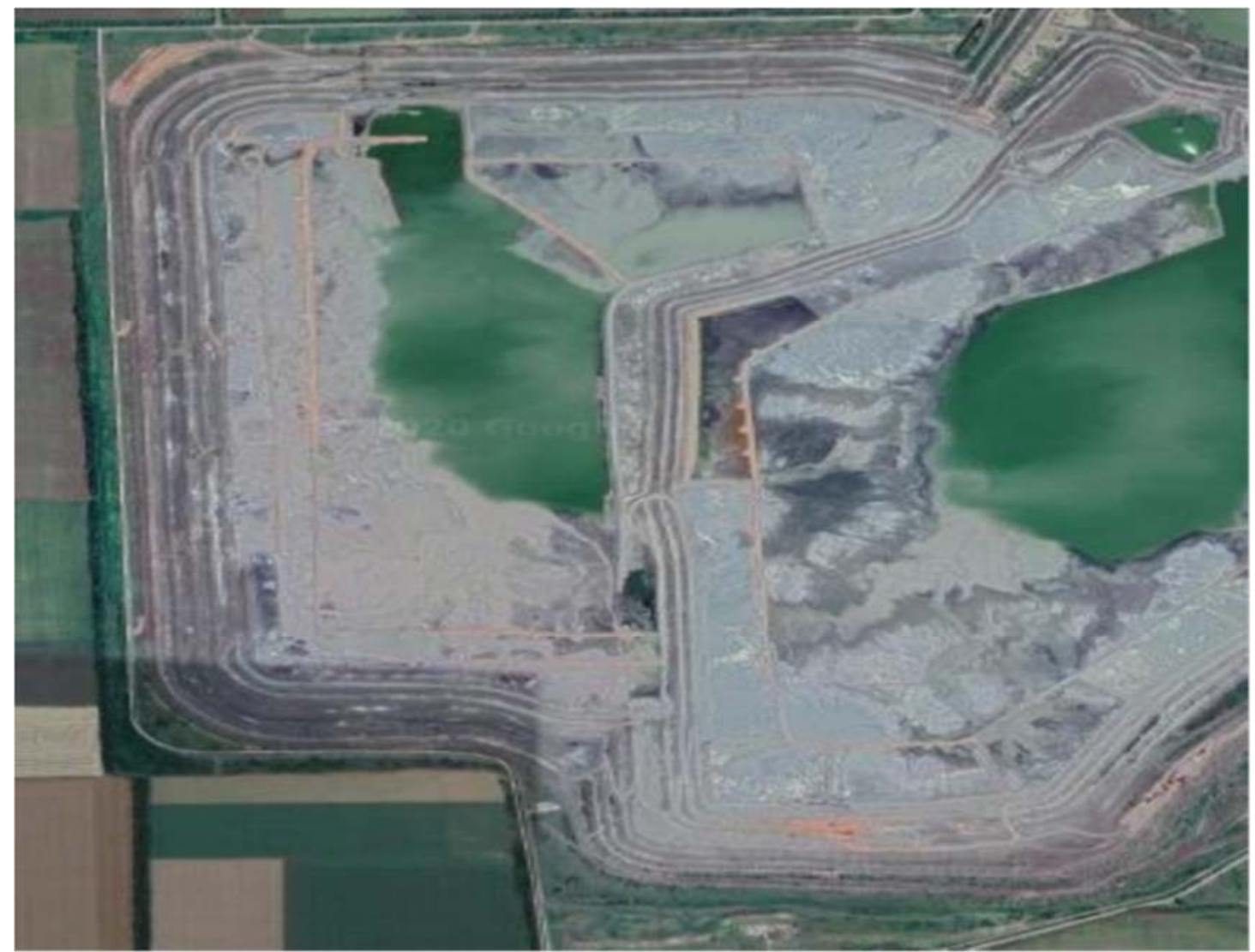

Fig. 8. Managed dump-sites with iron tailings.

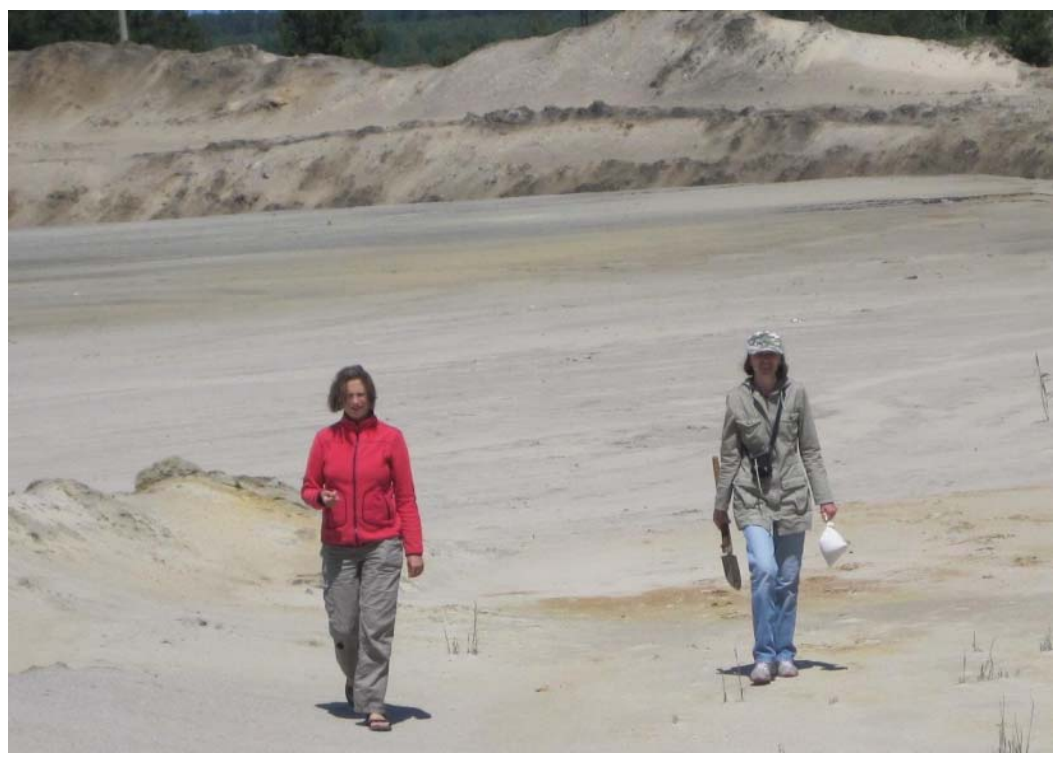

Fig. 9. Waste from mineral processing of Irshansk Mining and Processing Plant.

The predominant part of the waste $(78 \%)$ from major metals production is metallurgical and ferroalloy slags. Metallurgical sludge is the dust captured by air purifying equipment using liquid filters. It is stored in sludge collectors. After settling, the water is discharged into the surface water bodies, while the solids, if not reused, are accumulated at the managed dump-sites. Red mugs are generated at two enterprises - Mykolaiv alumina refinery and Zaporizhzhia alumina processing plants which produce alumina from bauxite. As can be seen from the chart (Fig. 6), the red mug makes $10 \%$ of the total waste from the major metal production.
One of the ways to reduce the amount of waste at the stage of extraction and processing of the metal ores in Ukraine is the integrated use of the mineral resources and the utilization of enrichment waste.

The chart shows that $96 \%$ of the waste generated by quarrying and mining is the metal ore waste and tailings from mineral processing (Fig. 7, 8).

The annual generation of iron tailings is over $130 \mathrm{mln}$. tons. Recycling of the tailings through ferrous concentrate and construction sand production will allow to decrease considerably the amount of the stored waste. 
The problem of metal ore quarrying and mining in Ukraine is that host rock is not used. For example, in case of selective extraction and separate storage, talcum, garnet, muscovite and quartz concentrates can be produced from talc-, garnet- and muscovite-shales, respectively. Clays can be used for production of expanded clay and ceramics. The host rock can also be used for production of building sand and natural pigments (ferrous oxide, ocher, seladonite etc.). Mineralogy and chemical composition of some host rocks have been studied and described in detail in [7-12, 14, 15].

Clay, sands and limestone-shells from the overburden can be attributed to the resource potential of the manganese ore production waste in Ukraine, which can be selectively extracted and subsequently used in the national economy. In addition, more than 400 million tons of manganese-containing sludge have been accumulated in sludge storage facilities, with a mass fraction of $\mathrm{Mn}$ $10.5-17.5 \%$. By sludge processing applying different schemes, it is possible to obtain manganese concentrate with a mass fraction of Mn from 35-41\% (high-gradient magnetic separation with flotation) to $50 \%$ (magneticchemical technology) with an extraction of Mn $65-68 \%$ and $64 \%$, respectively.

The enrichment waste prevails in the total amount of wastes from extraction and enrichment of heavy mineral titanium-zirconium sands. The overburden from the development of titanium-zirconium placer deposits in Ukraine (clay, loam, sand) is acceptable to be used for reclamation works.

Ore minerals in the technogenic sands of the Malyshevskyi deposit (the Volnogorsk MMC) are represented by zircon, rutile, leucoxen and ilmenite. Mostly they are concentrated in the fraction $-0.16+0.06$ $\mathrm{mm}$. Disten, sillimanite, staurolite and tourmaline have relatively significant contents.

Studies of the material composition of the waste from the Irshansk group of deposits have revealed that $60 \mathrm{wt} . \%$ of sands are represented by $0.5-0.125 \mathrm{~mm}$ grains; $5-15$ wt. $\%$ is the metallic fraction, $85-95$ wt.\% - the nonmetallic one. The ore minerals are mainly ilmenite, rutile, ilmenorutil and zircon. The presence of zircon as the main mineral carrier of zirconium is confirmed by the mass fraction of the latter in the waste $(0.05-0.5 \mathrm{wt} . \%)$. We consider that these technogenic sands can be used to produce titanium and zirconium as well as quartz sand (Fig. 9).

Eurostat and the State Statistics Committee of Ukraine keep records of waste generation by material as well. Subdivision of wastes by material based on EU and Ukrainian data (2016) is presented in Table $3[2,3]$.

Table 3. Waste generation by waste category in Ukraine and EU countries.

\begin{tabular}{|c|c|c|c|c|c|c|c|c|c|c|c|c|c|c|}
\hline Country & $\begin{array}{c}\text { Total } \\
\text { volume } \\
\text { in a } \\
\text { country, } \\
\text { mln. } \\
\text { tons }\end{array}$ & $\%$ & $\begin{array}{l}\text { Mineral } \\
\text { and } \\
\text { solid } \\
\text { waste, } \\
\text { mln. } \\
\text { tons }\end{array}$ & $\%$ & $\begin{array}{l}\text { Chemical } \\
\text { and } \\
\text { medical } \\
\text { waste, } \\
\text { mln. tons }\end{array}$ & $\%$ & $\begin{array}{l}\text { Animal } \\
\text { and } \\
\text { plant } \\
\text { waste, } \\
\text { mln. } \\
\text { tons }\end{array}$ & $\%$ & $\begin{array}{c}\text { Sludges, } \\
\text { mln. } \\
\text { tons }\end{array}$ & $\%$ & $\begin{array}{c}\text { Reprocessing } \\
\text { of waste, } \\
\text { mln. tons }\end{array}$ & $\%$ & $\begin{array}{l}\text { Equipment, } \\
\text { mln. tons }\end{array}$ & $\%$ \\
\hline $\begin{array}{c}\text { Total EU, } \\
\text { million } \\
\text { tonnes }\end{array}$ & 2454.72 & 100.0 & 1796.6 & 73.19 & 54.15 & 2.21 & 95.28 & 3.88 & 20.71 & 0.84 & 246.13 & 10.03 & 17.83 & 0.73 \\
\hline Germany & 400.07 & 16.30 & 261.39 & 65.33 & & 2.23 & 15.62 & 3.91 & 1.49 & 0.37 & 39.38 & 9.84 & 2.43 & 0.61 \\
\hline France & 323.47 & 13.18 & 261.76 & 80.92 & & 1.53 & 11.81 & 3.65 & 1.21 & 0.37 & & 10.79 & & 0.75 \\
\hline England & 277.26 & 11.29 & 141.64 & 51.09 & 4.80 & 1.73 & 10.29 & 3.71 & 4.17 & 1.50 & 43.11 & 15.55 & 3.80 & 1.37 \\
\hline Poland & 182.01 & 7.41 & 122.71 & 67.42 & & 1.64 & 3.19 & 1.75 & 0.66 & 0.36 & & 7.45 & 0.70 & 0.39 \\
\hline Romania & 177.56 & 7.23 & 163.36 & 92.00 & & 0.54 & 0.86 & 0.49 & 0.20 & 0.11 & & 3.28 & 0.13 & 0.08 \\
\hline Italy & 164.00 & 6.68 & 65.46 & 39.91 & 14.29 & 8.71 & 7.85 & 4.79 & 6.08 & 3.70 & 28.10 & 17.14 & 3.03 & 1.85 \\
\hline Sweden & 141.62 & 5.77 & 101.83 & 71.90 & & 0.91 & 2.38 & 1.68 & 0.40 & 0.28 & 6.3 & 4.45 & 0.85 & 0.60 \\
\hline Netherlands & 141.02 & 5.75 & 104.04 & 73.77 & 2.40 & 1.70 & 15.20 & 10.78 & 0.66 & 0.47 & 8.39 & 5.95 & 0.54 & 0.39 \\
\hline Spain & 128.96 & 5.25 & 67.03 & 51.98 & 2.66 & 2.06 & 9.14 & 7.08 & 1.46 & 1.13 & 12.56 & 9.74 & 1.21 & 0.93 \\
\hline Amount & 1935.97 & 78.87 & 1289.21 & & 43.26 & & 76.35 & & 16.32 & & 192.14 & & 15.13 & \\
\hline $\begin{array}{c}\text { Other } \\
\text { countries }\end{array}$ & 518.75 & 21.13 & 507.39 & 26.81 & 10.89 & 97.79 & 18.93 & 96.12 & 4.39 & 99.16 & 53.99 & 89.97 & 2.70 & 99.27 \\
\hline Ukraine & 295.87 & & 226.20 & 76.4 & 1.44 & 0.49 & 13.89 & 4.69 & 3.90 & 1.32 & $\cdots$ & & $\cdots$ & \\
\hline
\end{tabular}

As indicated in table 3, over 2 billion tons of waste is generated annually in EU countries. The total volume of waste generated in all $28 \mathrm{EU}$ countries in 2018 was 2.6 billion tons. Mineral and solid waste constitutes the largest part of the total waste generated in all countries from $39.9 \%$ in Italy to $80.9 \%$ in France. In Ukraine, they constitute $76.4 \%$ of the total waste generated.

In the EU countries, various amounts of waste are generated from waste recycling - from $6 \%$ in Netherlands to $16 \%$ in the United Kingdom. In Ukraine, the amount of waste from waste recycling is only $0.07 \%$.
Fig. 10 shows waste accumulation at managed dumpsites in different regions in Ukraine [3].

The chart shows the amount of waste accumulated at managed dump-sites in different regions in Ukraine. Based on this amount the regions were divided into 3 groups. The first includes areas accommodating hundreds of millions of tons of waste. The second - tens of millions of tons. The third - less than 10 million tons.

Having the well-developed industry Dnipropetrovsk region accommodates the largest volumes of waste. The plants extract and enrich iron, manganese, titanium- 
zirconium ores and coal. There are also metallurgical and ferroalloy plants.

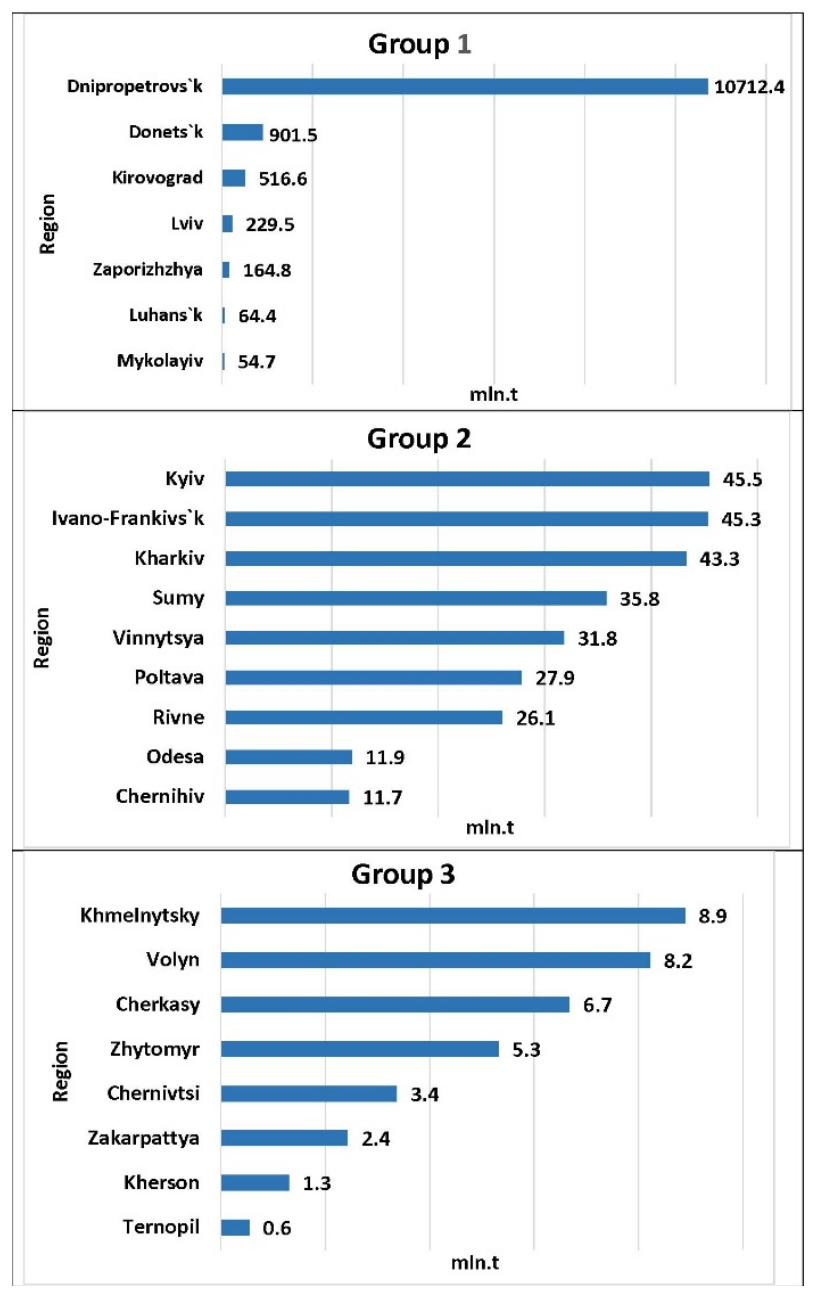

Fig. 10. Waste accumulation in different regions in Ukraine.

As can be seen from the chart, Dnipropetrovsk region accumulated 10 billion tons of waste at the disposal sites.

According to our estimates. More than $90 \%$ of it is waste from extraction and processing of iron and manganese ores (Kryvbas mining and processing integrated plant. Nikopol manganese ore field and metallurgical plants).

In Donetsk region, at the territory controlled by the Ukraine authorities most of the waste is accumulated at the coal mining and enrichment plants, coke plants and metallurgical plants. Dokuchaiv flux-dolomite plant which accumulated huge amounts of waste by 2013 is located at the temporarily occupied territories and the data are not available.

In Kirovohrad region, $99.9 \%$ of waste is accumulated at three enterprises: Petrivskyi quarry of the Central mining and processing complex, gulch "Shcherbakivska" and mine "Inhulska" of the Eastern mining and processing plant. Petrivskyi quarry's disposal sites accommodate almost $80 \%$ of the waste accumulated in Kirovohrad region.

In Lviv region over $96 \%$ of waste is accumulated at four enterprises: JSC "Lviv Coal Company". 6 mines of
SE "Lvivvuhillia". Novoiavorivske SE "Ekotransenergo" and Dobrotvirska TPP.

In Zaporizhzhia region almost $90 \%$ of waste was accumulated at 5 enterprises. i.e. JSC "Zaporizhstal" (metallurgical (iron) slag and sludge). Zaporizhzhia TPP (coal ash). LLC "Remondis Zaporizhzhia" (household waste). JSC "Zaporizhzhia Ferroalloy Plant" (ferroalloy slag and dust from gas purification plants) and JSC "Zaporizhzhia Aluminum Production Plant" (over 10 million tons of red sludge).

In Luhansk region, at the territory controlled by the Ukrainian authorities there are coal enterprises which generate coal mining and enrichment waste.

The second group comprises the Ukrainian regions which accommodate the most powerful TPPs (Trypilska, Zmiivska, Ladyzhynska and Burshtynska). These TPPs produce $60-70 \%$ of the total waste generated in a region.

The third group includes regions in which $70-99 \%$ of the total waste is municipal waste.

It should be noted that the volume of accumulated waste in Ukraine is much higher than the mentioned above. This is because the State Statistics Service receives information only from operating enterprises. Large volumes of waste are stored at enterprises abandoned after disintegration of the Soviet Union.

According to the Ministry of Energy and Environmental Protection data, 35 billion tons of waste have been accumulated in the country. 14 of the largest waste generators are located in Dnipropetrivsk region, 9 in Donetsk, 3 - in Poltava, 2 in Kirovohrad and Zaporizhzhia and 1 in Ivano-Frankivsk, Mykolaiv, Ternopil and Lviv regions.

6 out of 35 largest waste generators are Kryvbas mining and processing enterprises which exploit iron ore deposits (Table 4) [6].

Table 4. Largest waste generators and polluters of the environment in Ukraine.

\begin{tabular}{|c|l|c|}
\hline № & \multicolumn{1}{|c|}{ Company name } & $\begin{array}{c}\text { Generated waste. } \\
\text { mln. tons }\end{array}$ \\
\hline 1. & Northern Mining and Processing Plant & 81.34 \\
\hline 2. & Inhulets Mining and Processing Plant & 63.48 \\
\hline 3. & Central Mining and Processing Plant & 61.56 \\
\hline 4. & ArcelorMittal Kryvyi Rih & 27.65 \\
\hline 5. & Southern Mining and Processing Plant & 26.92 \\
\hline 6. & $\begin{array}{l}\text { Yerystivskyi Mining and Processing } \\
\text { Plant }\end{array}$ & 14.95 \\
\hline 7. & Novotroitske Ore Mining Company & 6.74 \\
\hline 8. & Ilyich Iron and Steel Works & 6.23 \\
\hline 9. & $\begin{array}{l}\text { Processing Integrated Plant } \\
\text { 10. }\end{array}$ & $\begin{array}{l}\text { Pokrovskyi Mining and Processing } \\
\text { Plant }\end{array}$ \\
\hline 11. & Total & 3.86 \\
\hline
\end{tabular}

The enterprises listed in the table except for PJSC "Ilyich Iron and Steel Works" are the mining and processing plants that predominantly accumulate overburden iron and manganese ore enrichment waste.

In Ukraine, $14 \mathrm{mln}$. tons of iron ore waste from mining and processing plants are dumped on over 7 thousand hectares. The article [13] presents a list of alternative 
minerals which can be extracted from Kryvbas iron ore deposits. Technologic solutions for waste management and mineral extraction from tailings and host rock are described in the papers [16-18]. Enrichment technologies have been developed under laboratory conditions.

The problem of complex use of the deposits in order to reduce technogenic impact is predominantly the economic and political one. Extraction of iron ore concentrate from the enrichment waste at the Central mining and processing complex (Kryvyi Rih) has shown that its cost is $40 \%$ lower than the concentrate extracted from the quarried ore; its quality is only slightly lower.

We believe that it is possible to reduce the technogenic impact on the environment by recycling of tailings and more comprehensive and effective use of mineral deposits.

\section{Conclusions}

Analysis of industrial waste showed that the amount of its generation in Ukraine correspond to that in France. Poland and Romania (300-400 million tons per year). In Ukraine the largest amounts of waste are generated from the quarrying and mining (74.3\%). and manufacturing $(13.2 \%)$ industries. In Germany and France, for example, the largest amount of waste is generated from construction (55.6\% and $70.2 \%$. respectively), manufacturing $(13.9 \%$ and $6.6 \%$. respectively) and waste/water $(11.9 \%$ and $6.8 \%$. respectively).

The impact of industrial waste from mining and mineral processing on the environment can be reduced by application of innovative technologies in ore extraction and enrichment and in metallurgical industry. It will increase the degree of extraction of useful components from the mineral resources and improve the monitoring of waste disposal sites. Solution of the above problems depends on the legislation and the willingness of business to invest in diversification of production.

\section{References}

1. Statistical yearbook. Environment of Ukraine 2018. http://www.ukrstat.gov.ua/druk/publicat/kat_u/2019/ zb/11/Zb_dovk_2018.pdf. Accessed 13 Mar 2020

2. Generation of waste by waste category. https://ec.europa.eu/eurostat/databrowser/view/ten0 0106/default/table?lang=en. Accessed 13 Mar 2020

3. Statistical yearbook. Environment of Ukraine 2017 http://www.ukrstat.gov.ua/druk/publicat/kat_u/2018/ zb/11/zb_du2017.pdf. Accessed 13 Mar 2020

4. National Report on the State of the Environment of Ukraine in 2010 (Center for Environmental Information and Education. Kyiv. 2011)

5. National report on the state of the environment in Ukraine in 2011 (Ministry of Ecology and Natural Resources of Ukraine. LAT \& K. 2012)

6. Top 100 largest pollutants. https://menr.gov.ua/ news/34251.html. Accessed 13 Mar 2020
7. N.I. Maksymenko, Morphological features of the talc horizon of Kryvyi Rih basin. GeologicalMineralogical Journal 2. 88-92 (2001)

8. V.A. Sytai, V.D. Yevtekhov. V.B. Matys, Talc of Kryvyi Rih basin: prospects for industrial application. Geological-Mineralogical Journal 1. 7175 (2004)

9. V.V. Stetsenko, V.D. Yevtekhov, Variations in chemical composition of muscovite from Skelevatskaya suite of Kryvyi Rih basin. GeologicalMineralogical Journal 2. 21-52 (2003)

10. V.V. Stetsenko, V.D. Yevtekhov, Muscovite of Kryvyi Rih basin. Mineral resources of Ukraine 6-8 (2001)

11. Yu.L. Akhkozov, V.I. Gladkikh. L.L. Liazhenko et al., Manifestations of pigment raw materials in the deposits developed by Kryvyi Rih mining and processing plants. Collection of papers "Scientific and technical aspects of stabilization in mining industry" 192-197 (1996)

12. V.D. Blokha, Kryvbas subsoil - source of gemstones and collectible minerals. Geological-Mineralogical Journal 1(17). 80-82 (2007)

13. V.D. Yevtekhov. I.S. Paranko. E.V, Yevtekhov. Alternative mineral and raw materials base of Kryvyi Rih iron ore basin (KTU Publishing House. Kryvyi Rih. 1999)

14. L.N. Kovalchuk. V.D. Yevtekhov, Mineralogical substantiation of the garnet-containing shale preparation for enrichment. Statements of Academy of Mining Sciences of Ukraine 4. 45-49 (1997)

15. A.I. Katalanets, O.K. Valeev, On possibility of shaleporite production from rocks of Skelevatskaya magnetite deposite (YuMPP). Collection of papers of National Mining University 1(14). 52-58 (2002)

16. T.V. Dendiuk, A.D. Yurtaeva, K.I. Shostak, K.V. Tymoshenko, V.G. Lytovka, Semi-industrial tests and development of Inhulets MPP talc shale enrichment technology in Storage and disposal of waste from ferrous metal ore processing (Nedra. Moscow. 1991). pp. 84-88

17. Yu.P. Kaplenko, G.T. Faustov, M.B. Fedko et al., Assessment of possibility of Kryvyi Rih basin's talc shale improving by water classification. Development of ore deposits 2. 39-43 (2000)

18. L.N. Kovalchuk, V.D. Yevtekhov, L.T. Dudar, Mineralogy of gravitational enrichment of hypergenously unchanged garnet-containing shale from Annovsky deposit (Kryvyi Rih basin). Geological-Mineralogical Journal 1-2. $72-76$ (2001) 